\title{
The 'Maffei 15' Lima Bean Compensates for Reduced Plant Stand
}

\author{
Wallace G. Pill, Thomas A. Evans, Michael W. Olszewski, \\ Robert P. Mulrooney, and Walter E. Kee, Jr. \\ Department of Plant and Soil Sciences, University of Delaware, Newark, \\ DE 19717-1303
}

Additional index words. Phaseolus lunatus, population, population density

\begin{abstract}
Maffei 15' baby lima bean seeds were sown every $6 \mathrm{~cm}$ in rows $76 \mathrm{~cm}$ apart to yield a nominal stand of 215,000 plants/ha at two locations in Delaware over 2 years. Seedlings were thinned within 2 weeks of planting to provide $0 \%, 16.7 \%, 33.3 \%$, and $50.0 \%$ stand reduction at two in-row spacing patterns to determine subsequent effects on vegetative and reproductive growth. Shoot fresh weight per square meter was decreased only in 2003 by $21 \%$ and bean fresh weight per square meter was decreased only in 2004 by $13.8 \%$ when plant stand decreased to $\mathbf{5 0 \%}$. This disproportional vegetative and reproductive growth response to stand reduction resulted from a compensatory linear increase in shoot fresh weight, usable pod number, and bean fresh weight of individual plants. Thus, 'Maffei 15' lima bean tolerates a considerable loss of plant stand with little or no effect on yield.
\end{abstract}

The green lima bean is a major processing crop in the mid-Atlantic region with 7200 ha planted annually (Tarburton et al., 2000) and Delaware producing about $40 \%$ of the lima beans sold in the United States. The effects of stand reduction on economic yield of baby lima beans have not been examined. Lima bean stands in Delaware can be reduced significantly by infection primarily from Rhizoctonia solani (Mulrooney et al., 2004). Stands of lima bean and other warm-season crops also can be reduced by imbibitional injury (Pollock, 1969; Pill and Kabilan, 1999) when seeds of low initial seed moisture rapidly imbibe causing an accumulation of intercotyledonary water that hinders oxygen transfer to the embryo axis. Other reasons for reduced stand could include planter malfunction, herbicide injury or soil crusting.

Smith(1980) showed that economic yield of 'Fodhook 242' lima bean, a large-seeded type, was unaffected as plants decreased from 16 to 11 per $\mathrm{m}$ of row. Although there are no known reports of the effects of baby lima bean stand reduction on crop growth and yield, the effects of plant population density have been reported. A positive correlation between seed yield of individual lima bean plants and their shoot dry matter production is documented (Fisher and Weaver, 1974; Lambeth, 1950; Rappaport and Carolus, 1956; Smittle, 1986). An inverse relationship between plant population density and lima bean economic yield has occurred with closer in-row spacing (Lachman and Snyder, 1943; Larson and Peng-Fi, 1948; Matthews, 1933), and closer row spacing (Larson and Peng-Fi, 1948). Presumably, the higher population density was unable to compensate for the reduced yield from the smaller plants. Sirait et al. (1994) noted that narrower rows increased economic yield of 'Maffei 15' lima beans, but only with irrigation, which increased leaf area index and shoot dry matter production per unit land area.

Received for publication 5 Aug. 2005. Accepted for publication 29 Aug. 2005.
Yield reductions were not proportional to percent stand reductions in soybean (Glycine $\max$ L. Merr.) because of the compensating ability of the remaining plants to develop more branches and pods (Johnson and Harris, 1967; Stivers and Swearingin, 1980). In fact, Torii et al. (1987) reported that a $25 \%$ reduction in plant stand reduced soybean yield by only $10 \%$, and Vasilas et al. (1990) reported that a $66 \%$ stand reduction, imposed uniformly, and as gaps, reduced soybean yields by only 7 and $27 \%$, respectively. Yield loss associated with replanting was greater than yield loss associated with a stand reduction of up to $66 \%$ (Vasilas et al., 1990).

The objective of our study was to determine the effects of stand reduction on vegetative and reproductive responses of 'Maffei 15' baby lima beans.

\section{Materials and Methods}

The study was conducted during June to September on Kalmia loamy sand (fine loamy silicaceous, thermic Typic Hapludult) near Georgetown, Del. (lat. $38.7^{\circ} \mathrm{N}$, long. $75.3^{\circ} \mathrm{W}$ ) in 2003, and on Matapeake silt loam (fine silty, mixed mesic Typic Hapludult) in Newark, Del. (lat. $37.3^{\circ} \mathrm{N}$, long. $75.5^{\circ} \mathrm{W}$ ) in 2004 . Seeds of 'Maffei 15' lima bean were machine planted every $6 \mathrm{~cm}$ in rows $76 \mathrm{~cm}$ apart to provide a nominal stand of 215,000 seeds/ha. Plant population densities were created by hand removal of plants within 2 weeks of planting. In addition to the full stand ( $0 \%$ stand reduction), three percentages of stand reduction were created at two in-row spacings (gaps) by removing plants. The percentages and gaps were $16.7 \%$ (one plant out of every consecutive six, or two consecutive plants out of every twelve); $33.0 \%$ (one plant out of every consecutive three, or two consecutive plants out of every six); and 50\% (every other plant, or two consecutive plants out of every four). Each treatment consisted of four 6-m-long rows.

The 4 (stand reduction) $\times 2$ (gaps) factorial experiment was arranged in randomized block design with four replications. Blocks consisted of four 6-m-long rows per treatment with two border rows on each side. Plots received $90 \mathrm{~kg}$ $\mathrm{N} /$ ha from $14 \mathrm{~N}-3 \mathrm{P}-12 \mathrm{~K}(14-7-14)$ on the day of planting. Imazethapur herbicide was incorporated preplant at $36 \mathrm{~g}$ a.i./ha. Manual cultivation subsequently controlled weeds. Other pest control measures followed Univ. of Delaware (2003) recommendations. Plots received at least $50 \mathrm{~mm}$ of water each week from rain or irrigation from planting to harvest.

At the time of harvest, plants from the central 3 m of the two inner rows of each treatment were pulled out of the ground, counted and weighed. Pods were manually stripped from plants and separated and counted as flat (immature), usable (green), and dry (overly mature). The green pods were threshed mechanically and the seed fresh weight (economic yield) determined. All data were recorded on a per plant and per unit area $\left(\mathrm{m}^{2}\right)$ basis. In 2004, the numbers of nodes and branches on 10 plants from each treatment-replication combination were counted.

\section{Results and Discussion}

Since in-row gaps had no effect on any variable in either year, only the results of percentage stand reduction are reported. Kahn et al. (1995) similarly noted that seed yield and harvest index of cowpea [Vigna unguiculata (L.) Walp] was unaffected by uniformity of within-row spacing. The 17.8 and 20.0 plants $/ \mathrm{m}^{2}$ achieved in 2003 and 2004, respectively, with no stand reduction (Table 1) represented $83 \%$ and $93 \%$ of the potential stand of $215,000 \mathrm{plants} / \mathrm{ha}$. The nominal $16.7 \%, 33.3 \%$, and $50.0 \%$ nominal stand reductions were, respectively, $23.6 \%$, $35.9 \%$, and $49.4 \%$ in 2003 , and $19.5 \%, 31.5 \%$, and $49.5 \%$ in 2004 .

As stand decreased from $100 \%$ to $50 \%$, shoot fresh weight per square meter decreased only $21 \%$ in 2003 and was unaffected in 2004 ; while bean fresh weight per square meter was unaffected in 2003 and decreased only $13.8 \%$ in 2004 (Table 1). This absence or less than proportional decrease in shoot or bean fresh weight in response to stand reduction has been reported in soybean (Johnson and Harris, 1967; Stivers and Swearingin, 1980; Torii et al., 1987; Vasilas et al., 1990) and large-seeded lima bean (Smith, 1980), and reflects the ability of plants to respond vegetatively and reproductively in a compensating manner to the decreasing population density.

The numbers of flat, dry or usable pods $/ \mathrm{m}^{2}$ were unaffected by stand reduction in either year. In both years, the usable pods were $87 \%$ of the total pod number per plant, indicating that plant population density had no effect on crop maturation rate.

Linear increases in shoot fresh weight, number of usable pods and bean fresh weight of individual plants in response to decreasing stand during both years (Table 2) confirmed the ability of plants to respond positively to reduced population density. Early research revealed the positive correlation between seed yield and vegetative growth of lima bean plants (Fisher and Weaver, 1974; Lambeth, 1950; Rappaport and Corolus, 1956; Smittle, 1986). Decreas- 
Table 1. Plant population, shoot fresh weight, number of pods (flat, dry and usable), and bean fresh weight on a per area basis in response to stand reduction of 'Maffei 15' lima bean during 2003 and 2004.

\begin{tabular}{|c|c|c|c|c|c|c|c|c|c|c|c|c|}
\hline \multirow{2}{*}{$\begin{array}{l}\text { Stand } \\
\text { reduction } \\
(\%)\end{array}$} & \multicolumn{2}{|c|}{$\begin{array}{c}\text { Plant } \\
\text { population } \\
\text { (plants } / \mathrm{m}^{2} \text { ) }\end{array}$} & \multicolumn{2}{|c|}{$\begin{array}{l}\text { Shoot } \\
\text { fresh wt } \\
\left(\mathrm{g} \cdot \mathrm{m}^{-2}\right)\end{array}$} & \multicolumn{2}{|c|}{$\begin{array}{c}\text { Flat } \\
\text { pods } \\
\text { (pods } / \mathrm{m}^{2} \text { ) }\end{array}$} & \multicolumn{2}{|c|}{$\begin{array}{c}\text { Dry } \\
\text { pods } \\
\text { (pods } / \mathrm{m}^{2} \text { ) }\end{array}$} & \multicolumn{2}{|c|}{$\begin{array}{c}\text { Usable } \\
\text { pods } \\
\text { (pods } / \mathrm{m}^{2} \text { ) }\end{array}$} & \multicolumn{2}{|c|}{$\begin{array}{c}\text { Bean } \\
\text { fresh wt } \\
\left(\mathrm{g} \cdot \mathrm{m}^{-2}\right)\end{array}$} \\
\hline & 2003 & 2004 & 2003 & 2004 & 2003 & 2004 & 2003 & 2004 & 2003 & 2004 & 2003 & 2004 \\
\hline$\overline{0}$ & 17.8 & 20.0 & 2378 & 3548 & 9.2 & 18.8 & 11.4 & 20.6 & 164 & 323 & 353 & 608 \\
\hline 16.7 & 13.6 & 16.1 & 2262 & 3602 & 8.7 & 16.2 & 13.1 & 30.6 & 155 & 298 & 308 & 546 \\
\hline 33.3 & 11.4 & 13.7 & 2165 & 3719 & 9.2 & 17.1 & 14.8 & 26.2 & 154 & 301 & 341 & 586 \\
\hline 50.0 & 9.0 & 10.1 & 1874 & 2836 & 10.1 & 20.6 & 12.7 & 24.1 & 160 & 293 & 288 & 524 \\
\hline Significance & $\mathrm{L}^{* * *}$ & $\mathrm{~L}^{* * *}$ & $\mathrm{~L}^{\mathrm{NS}}$ & $\mathrm{L}^{\mathrm{NS}}$ & $\mathrm{L}^{\mathrm{NS}}$ & $\mathrm{L}^{\mathrm{NS}}$ & $\mathrm{L}^{\mathrm{NS}}$ & $\mathrm{L}^{\mathrm{NS}}$ & $\mathrm{L}^{\mathrm{NS}}$ & $\mathrm{L}^{*}$ & $\mathrm{~L}^{*}$ & $\mathrm{~L}^{\mathrm{NS}}$ \\
\hline & $\mathrm{Q}^{*}$ & $\mathrm{Q}^{* * *}$ & $\mathrm{Q}^{\mathrm{NS}}$ & $\mathrm{Q}^{\mathrm{NS}}$ & $\mathrm{Q}^{\mathrm{NS}}$ & $\mathrm{Q}^{\mathrm{NS}}$ & $\mathrm{Q}^{\mathrm{NS}}$ & $\mathrm{Q}^{\mathrm{NS}}$ & $\mathrm{Q}^{\mathrm{NS}}$ & $\mathrm{Q}^{\mathrm{NS}}$ & $\mathrm{Q}^{\mathrm{NS}}$ & $\mathrm{Q}^{\mathrm{NS}}$ \\
\hline $\mathrm{LSD}_{005}$ & 3.1 & 2.6 & 349 & 721 & 5.7 & 8.3 & 5.9 & 12.8 & 19 & 32 & 70 & 31 \\
\hline
\end{tabular}

$\mathrm{NS},{ }^{* * * * *}$ Nonsignificant or significant at $P \leq 0.005$ or 0.001 , respectively; $\mathrm{L}=$ linear, $\mathrm{Q}=$ quadratic.

Table 2. Per plant shoot fresh weight, number of pods (flat, dry and usable), and bean fresh weight in response to stand reduction of 'Maffei 15 ' lima bean during 2003 and 2004, and number of nodes and branches per plant in 2004.

\begin{tabular}{|c|c|c|c|c|c|c|c|c|c|c|c|c|}
\hline \multirow{2}{*}{$\begin{array}{l}\text { Stand } \\
\text { reduction } \\
(\%)\end{array}$} & \multicolumn{2}{|c|}{$\begin{array}{c}\text { Shoot } \\
\text { fresh wt } \\
\text { (g/plant) }\end{array}$} & \multicolumn{2}{|c|}{$\begin{array}{c}\text { Flat } \\
\text { pods } \\
\text { (no./plant) }\end{array}$} & \multicolumn{2}{|c|}{$\begin{array}{c}\text { Dry } \\
\text { pods } \\
\text { (no./plant) }\end{array}$} & \multicolumn{2}{|c|}{$\begin{array}{c}\text { Usable } \\
\text { pods } \\
\text { (no./plant) }\end{array}$} & \multicolumn{2}{|c|}{$\begin{array}{c}\text { Bean } \\
\text { fresh wt } \\
\text { (g/plant) }\end{array}$} & \multirow{2}{*}{$\begin{array}{c}\text { Nodes/ } \\
\text { plant } \\
\text { (no.) }\end{array}$} & \multirow{2}{*}{$\begin{array}{c}\text { Branches/ } \\
\text { plant } \\
\text { (no.) }\end{array}$} \\
\hline & 2003 & 2004 & 2003 & 2004 & 2003 & 2004 & 2003 & 2004 & 2003 & 2004 & & \\
\hline$\overline{0}$ & 134 & 173 & 0.5 & 1.0 & 0.6 & 1.1 & 9.2 & 18.1 & 15.6 & 34.1 & 4.33 & 8.5 \\
\hline 16.7 & 159 & 224 & 0.7 & 1.2 & 0.9 & 2.3 & 10.9 & 21.9 & 22.9 & 40.3 & 5.73 & 12.2 \\
\hline 33.3 & 188 & 272 & 0.8 & 1.2 & 1.3 & 2.3 & 13.4 & 26.4 & 28.9 & 51.4 & 7.09 & 16.5 \\
\hline 50.0 & 209 & 282 & 1.0 & 2.3 & 1.4 & 2.7 & 17.8 & 32.6 & 35.9 & 58.2 & 7.86 & 19.1 \\
\hline \multirow[t]{2}{*}{ Significance } & $\mathrm{L}^{* *}$ & $\mathrm{~L}^{*}$ & $\mathrm{~L}^{\mathrm{NS}}$ & $\mathrm{L}^{* * *}$ & $\mathrm{~L}^{\mathrm{NS}}$ & $\mathrm{L}^{\mathrm{NS}}$ & $\mathrm{L}^{*}$ & $\mathrm{~L}^{*}$ & $\mathrm{~L}^{* *}$ & $\mathrm{~L}^{* * * *}$ & $\mathrm{~L}^{* * *}$ & $\mathrm{~L}^{* * * *}$ \\
\hline & $\mathrm{Q}^{\mathrm{NS}}$ & $\mathrm{Q}^{\mathrm{NS}}$ & $\mathrm{Q}^{\mathrm{NS}}$ & $\mathrm{Q}^{*}$ & $\mathrm{Q}^{\mathrm{NS}}$ & $\mathrm{Q}^{\mathrm{NS}}$ & $\mathrm{Q}^{\mathrm{NS}}$ & $\mathrm{Q}^{\mathrm{ns}}$ & $\mathrm{Q}^{\mathrm{NS}}$ & $\mathrm{Q}^{\mathrm{NS}}$ & $\mathrm{Q}^{\mathrm{ns}}$ & $\mathrm{Q}^{\mathrm{NS}}$ \\
\hline $\mathrm{LSD}_{005}$ & 13 & 8 & 0.8 & 0.3 & 3.4 & 5.5 & 2.8 & 3.9 & 5.1 & 6.4 & 0.87 & 2.3 \\
\hline
\end{tabular}

ing stand from $100 \%$ to $50 \%$ resulted in linear increases in number of nodes and branches per plant of $81.5 \%$ and $124.7 \%$, respectively. Seed yield of lima bean, similar to that of field bean (Vicia faba L.) (Pilbeam et al., 1990), is the product of several components: plant population density, podding nodes per plant, pods per podding node, seeds per pod, and single seed weight. The positive relationship between the number of usable pods or bean fresh weight with the numbers of nodes and branches per plant in response to decreasing plant stand may indicate that the increase in branches supported the increase in reproductive structures.

The reproductive structures of lima beans are indeterminate racemes, with the first flowers produced on the early inflorescences being the most critical for fruit production (Lambeth, 1950; Wootten et al., 1999). It remains unknown whether the greater pod set or retention and bean fresh weight of individual plants with decreasing plant stand (Table 2) was associated with more racemes borne on more branches. The greater leaf area per plant may have decreased the temperature and increased the relative humidity within the canopy, conditions that favor pod set and retention (Fisher and Weaver, 1974). Even though decreasing stand promoted more nodes and branches on individual plants, the observed delay in ground cover at lower population densities may favor weed growth. Sankula et al. (2001) determined, however, that neither herbicide rate nor application method affected lima bean biomass or yield, weed density, control, or biomass production.

The results of this study have shown that reducing 'Maffei 15' lima bean stand by up to $50 \%$ reduced bean fresh weight per unit area by only $16 \%$, averaged over 2 years. This disproportional relationship resulted from increased vegetative growth and reproductive yield of individual plants which compensated for the re- duced plant stand. It remains unknown whether indeterminate lima beans would compensate similarly for reduced plant stand. Cultivar growth habit (determinate $v s$ indeterminate) affected the compensatory response of field bean (Pilbean et al., 1990), but not of soybean (Pepper and Walker (1988).

\section{Literature Cited}

Fisher, V.J. and C.K. Weaver. 1974. Flowering, pod set, and pod retention of lima bean in response to night temperature, humidity, and soil moisture. J. Amer. Soc. Hort. Sci. 99:448-450.

Johnson,B.J. and H.B. Harris. 1967. Influence of plant population on yield and other characteristics of soybeans. Agron. J. 59:447-449.

Kahn, B.A., P.J. Stoffella, D.L. Leskovar, and J.R. Cooksey. 1995. Yield of indeterminate, small vine cowpea cultivars unaffected by within-row spacing. HortScience 30:994-996.

Lachman, W.H. and G.B. Snyder. 1943. Experiments with lima beans. Proc. Amer. Soc. Hort. Sci. 42:554-556.

Lambeth, V.N. 1950. Some factors influencing pod set and yield of the lima bean. Univ. Mo. Agr. Expt. Sta. Res. Bul. 466.

Larson, R.E. and L. Peng-Fi Li. 1948. The influence of various row and plant spacings on yield of lima beans. Proc. Amer. Soc. Hort. Sci. 51:479-485.

Matthews, W.A. 1933. The influence of planting distances on the yield of snap and lima beans. Proc. Amer. Soc. Hort. Sci. 30:567-570.

Mulrooney, R.P., W.G. Pill, and T.A. Evans. 2004 Evaluation of seed treatment fungicides for the control of seedling diseases of baby lima beans, 2003. Fungicide Nematicide Test 56:ST032

Pepper, G.E. and J.T. Walker. 1988. Yield compensation for stand deficiencies by determinate and indeterminate growth-habit soybean. Agron. J. $80: 1-4$.

Pilbeam, C.J., G. Duc, and P.D. Hebblethwaite. 1990. Effects of plant population density on springgrown field beans (Vicia faba) with different growth habits. J. Agr. Sci. 114:19-33.

Pill, W.G. and S. Kabilan. 1999. Germination of semi- hard seeds and non-semi-hard seeds of 'Maffei 15 ' lima bean in response to matric priming. Acta Hort. 504:177-189.

Pollock, B.M. 1969. Imbibitional temperature sensitivity of lima bean seeds controlled by initial seed moisture. Plant Physiol. 44:907-911.

Rappaport, L. and R.L. Carolus. 1956. Effects of night temperature at different stage of development on reproduction in the lima bean. Proc. Amer. Soc Hort. Sci. 67:421-428.

Sankula, S., M.J. VanGessel, and W.E. Kee, Jr. 2001. Narrow row spacing does not affect lima bean yield or management of weeds and other pests. HortScience 36:884-888.

Sirait,Y., W.G. Pill, and W.E. Kee, Jr. 1994. Lima bean (Phaseolus lunatus L.) response to irrigation regime and plant population density. HortScience 29:71-73.

Smith, C.B. 1980. Growth responses and leaf nutrient concentrations of 'Fordhook 242' lima beans as affected by fertilizer treatment and plant stand. J. Amer. Soc. Hort. Sci. 105:472-475.

Smittle, D.A. 1986. Influence of cultivar and temperature on lima bean yield and quality. J. Amer. Soc. Hort. Sci. 111:655-659.

Stivers, R.K. and M.L. Swearingin. 1980. Soybean yield compensation with different populations and missing plant patterns. Agron. J. 72:98-102.

Tarburton, J.F., S. Stuchlik-Edwards, T.W. Fuerer, and R.R. Bosecker. 2000. Delaware agricultural statistics for 1999. Del. Dept. Agr., Newark.

Torii, K., B.L. Vasilas, S.G. Carmer, and C.A. Smyth. 1987. Growth and yield response of solid-seeded soybean to early season stand reduction. Agron. J. 79:555-558.

University of Delaware. 2003. 2003 Commercial vegetable production recommendations. Univ. Del. Ext. Bul. 137. Newark.

Vasilas, B.L., G.E. Pepper, and M.A. Jacob. 1990. Stand reductions, replanting, and offset row effects on soybean yield. J. Proc. Agr. 3:120-123.

Wootten, T.L., J.J. Frett, W.E. Kee, Jr., and J.D. Pesek. 1999. A comparison of production practices and fruit development for ' $\mathrm{M}-15$ ' lima beans grown in Delaware and California. J. Veg. Crop Prod. 5:73-89. 